\title{
Clinical and Molecular Aspects of Frontotemporal Dementia
}

\author{
Susanne Froelich-Fabre ${ }^{a, b}$ Lena Skoglund ${ }^{a}$ Jovanka Ostojic ${ }^{a}$ \\ Lena Kilander $^{a}$ Maria Lindau ${ }^{a}$ Anna Glaser ${ }^{a}$ Hans Basun ${ }^{a} b^{b}$ Lars Lannfelt $^{a}$ \\ a Department of Public Health and Caring Science, Division of Geriatrics, Uppsala University, Uppsala and \\ ${ }^{b}$ AstraZeneca R\&D, Research DMPK and Biomarkers, Södertälje, Sweden
}

\section{Key Words}

Frontotemporal lobe dementia - Clinical features . Neurofibrillary inclusions - Genetic aspects · Tau

\begin{abstract}
Frontotemporal dementia (FTD) is a neurodegenerative disease and next to Alzheimer's disease and vascular dementia, the third most common cause of early-onset progressive dementia. FTD leads to neurodegeneration in the frontal and temporal neocortex and usually encompasses both sides of the frontal and anterior temporal lobes. Psychologically, FTD is characterized by personality changes such as lack of insight, inappropriate behaviour, disinhibition, apathy, executive disabilities and a decline in cognitive functions, with large clinical and neuropathological variations among cases. Neuropathological characteristics include gliosis or microvacuolation of cortical nerve cells. Inclusions staining for tau protein and/or ubiquitin are also common findings. Both sporadic and hereditary forms of FTD have been identified and $30-50 \%$ of the FTD cases have a familial background. So far, at least three genetic loci for FTD have been identified, at human chromosomes 3,9 and 17 in familial forms of the disease. A large number of the familial forms have been linked to chromosome 17q21 and referred to as frontotemporal dementia and Parkin-
\end{abstract}

\section{KARGER}

Fax +41613061234

E-Mail karger@karger.ch

www. karger.com (c) 2004 S. Karger AG, Basel

1660-2854/04/0015-0218\$21.00/0

Accessible online at:

www. karger.com/ndd sonism linked to chromosome 17 . In the majority of these families, pathogenic mutations in the tau gene were identified. However, tau mutations seem to be a rare cause of disease in the general FTD population. Thus, other genes and/or environmental factors are yet to be identified, which will give further clues to this complex and heterogeneous disorder.

Copyright $@ 2004$ S. Karger AG, Basel

\section{Introduction}

Much of what is known about frontotemporal lobar degeneration (FTLD) descends from the findings of Arnold Pick [1] in the early 1890s. Pick described a 71-yearold man who developed transcortical sensory aphasia within the context of dementia. Symptoms like aggressiveness, infantile behaviour and memory deficits had preceded the admission to the hospital by $2-3$ years. At autopsy, the patient presented disproportionate atrophy of the left temporal lobe, apart from the superior temporal gyrus [1]. In the later examinations of Pick's tissue samples, another neuropathologist, Alois Alzheimer, observed swollen or 'ballooned' neurons, agrophilic and eosin-positive neuronal inclusions within frontal neurons in the absence of senile plaques and neurofibrillary tangles (NFT) [2]. Over time, the disease was referred to as Pick's
Lars Lannfelt

Department of Public Health and Caring Science, Geriatric Centrum, Box 609 SE-751 25 Uppsala (Sweden)

Tel. +461861171 89, +467066682 30, Fax +46 186117150

E-Mail Lars.Lannfelt@pubcare.uu.se 
disease (PiD) and the intraneuronal inclusions became known as Pick bodies. In the 1970s and 1980s, new diagnostic techniques revealed that frontotemporal degeneration also accounts for a variety of symptoms beside the language difficulties. In 1994, The Lund-Manchester group published the first clinical and neuropathological criteria for FTLD and adopted the clinical term 'frontotemporal dementia' (FTD) [3].

FTD is a heterogeneous group of dementias, both regarding clinical and pathological aspects and the nomenclature is broad, controversial and sometimes confusing. During the last decade, great efforts have been made to aid in the classification of this heterogeneous group. In 1998, The Lund-Manchester group updated the FTD consensus criteria with an extended concept 'frontotemporal lobar degeneration', which, apart from FTD, PiD and dementia with motor neuron disease (FTD/MND), also included progressive non-fluent aphasia and semantic dementia [4]. In this review, the term FTD will be used according to the first Lund-Manchester criteria.

\section{Clinical and Neuropathological Features of FTD}

FTD encompasses approximately $15-20 \%$ of the degenerative dementias and the onset is insidious, usually occurring between the ages of 45 and 65 years [5]. The incidence between the sexes is even. The most striking symptoms of FTD are behavioural and personality changes. Depending on the distribution of the pathology within the frontal and temporal lobes, there are three major FTD behavioural subtypes: the disinhibited type, the apathetic type and the dysexecutive type. Anatomically, the disinhibited type is connected with neurodegeneration of the orbitofrontal and anterior temporal neocortex; the apathetic type is associated with atrophy in the medial frontal-anterior cingulate region and the dysexecutive type is correlated with degeneration of the dorsolateral prefrontal. The disinhibited type is characterized by personality change, impulsivity, irritability, lability and socially inappropriate behaviour. The apathetic type lacks initiative and is emotionally indifferent, while the dysexecutive type has problems with planning, self-direction and ability to shift and maintain behavioural sets [6]. Admixtures between these types are common due to variations in the regional localisation of atrophy. Furthermore, patients often have word finding difficulties where speech is nonspontaneous, economical and often stereotyped. Progressive reduction in speech usually leads to mutism after several years of disease. Orientation in time and space, visuospatial skills and memory initially remain intact, but deteriorate with progression of the disease [7, 8]. Due to the degeneration of extrapyramidal neurons, parkinsonian signs may also be present, sometimes already from the onset of the disease. Parkinsonism involves bradykinesia, postural instability and rigidity without resting tremor. Some FTD patients also develop MND consistent with the diagnosis of amyotrophic lateral sclerosis (ALS).

Neuropathological features of FTD include neuronal degeneration in the frontal and temporal cortices, sometimes with subcortical changes, basal ganglia atrophy and depigmentation of the substantia nigra. Neurodegeneration usually encompasses both sides of the frontal and anterior temporal lobes symmetrically but can also appear asymmetrically in the hemispheric or predominantly temporal lobe. Furthermore, ballooned neurons are often observed. Due to histological differences, FTD can be further classified into three major subtypes [9]. The most common type (frontal lobar degeneration type) includes microvacuolation of the superficial neurons and spongiform changes. The second type (Pick type) is mainly characterized by widespread and abundant gliosis, in addition to swollen neurons and inclusion bodies in regions such as dentate gyrus. In the third form (MND type), patients suffer from MND in combination with pathology noticed in other subtypes. Classification into one of these subtypes is sometimes difficult when typical differentiating features are not always present. The evolving nomenclature as well as personal, regional and national preferences for specific diagnostic terms make the classification even cloudier.

\section{FTD Inclusions}

Neuronal inclusions are a common feature of most neurodegenerative disorders, which in familial forms often contain accumulations of fibrillar products of the defected gene causing the disease. To add even more complexity to the heterogeneous picture of FTD, there are at least three different types of intracellular inclusions identified in both neuronal and glial cells. These inclusions can be immunoreactive to the microtubule-associated protein tau, like NFTs and pick bodies or to ubiquitin [10-12]. Recently, inclusions staining for neurofilament were reported in cases with FTD/MND [13]. Tau inclusions seem to be the most abundant, as approximately $40 \%$ of the FTD cases (including the PiD subgroup) have cellular inclusions that stain positive for hyperphosphorylated forms of tau. However, there are large variations in quantity and characteristics [10, 14]. 


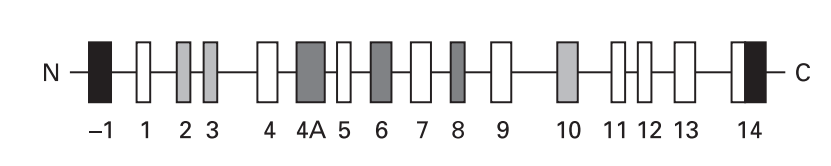

Fig. 1. Schematic structure of the tau gene. Exons -1 and 14 of the tau gene are transcribed but not translated. Exons 1, 4, 5, 7, 9, 11, 12 and 13 are constitutively expressed. Exons 4A, 6 and 8 are expressed only in 'big tau' in the peripheral nervous system, but not in the central nervous system. Exons 2, 3 and 10 are alternatively spliced.

\section{Tau Pathology in FTD and Other Tauopathies}

Inclusions staining for hyperphosphorylated tau protein are not only characteristic for FTD, but are also identified in other neurodegenerative disorders such as Alzheimer's disease, progressive supranuclear palsy (PSP), corticobasal degeneration, ALS-Parkinsondementia complex of Guam and prion diseases [15-19]. Due to the extensive pathology with filamentous aggregates of hyperphosphorylated tau, these syndromes are classified as tauopathies. Ultrastructurally, NFTs consist of paired helical filaments as a major fibrous component and straight filaments as a minor component. However, there are variations among the different tauopathies regarding the different tau species aggregated into NFTs causing differences in filament type and pattern of sarcosyl-insoluble tau.

The function of 'healthy' tau is to promote tubulin polymerisation and stabilisation of microtubules, which is important for axonal transport and cell polarity [20]. Tau is abundant in both the central and peripheral nervous systems, but has also been found in the heart, muscle, lung, testis, and skin [21,22]. The protein is encoded by a single gene, consisting of 16 exons which are located to chromosome 17q21 [23, 24] (fig. 1). Of these, exons 4A, 6 and 8 are mainly expressed in the peripheral nervous system and generate the longest tau isoforms known as 'big tau'. Exons 2, 3 and 10 undergo developmentally regulated alternative splicing, resulting in 6 isoforms ranging from 352 to 441 amino acids [25] (fig. 1). At the C-terminal domain of the tau protein, microtubule-binding domains are located $[25,26]$. These domains represent the 3 $(3 \mathrm{R})$ or $4(4 \mathrm{R})$ imperfect tandem repeats, generated due to alternative splicing of exon 10 (fig. 2). At the N-terminal, alternative splicing of exons 2 and 3 results in no, one or two 29- to 31-amino acid inserted sequences (fig. 2). Tau is post-translationally modified by phosphorylation in a


Fig. 2. Alternative splicing of exons 2,3 and 10 of the tau gene results in the 6 different tau isoforms in human adult brain. These isoforms can be denoted as $3 \mathrm{R}$ and $4 \mathrm{R}$ tau depending on the number of microtubule binding domains at the $\mathrm{C}$-terminal of the tau protein. Exon 10 encodes the fourth microtubule binding domain in 4R tau. The alternative splicing of exons 2 and 3 of the gene results in the two $(2 \mathrm{~N})$, one $(1 \mathrm{~N})$ or zero $(0 \mathrm{~N})$ insertions at the $\mathrm{N}$-terminal of the tau gene. Exon 3 never appears independently of exon 2.

dynamic process regulated by protein kinases and phosphatases during development. Foetal tau is extensively phosphorylated as compared to adult tau [27, 28]. Up to date, at least 22 phosphorylation sites of the tau protein have been described [29]. Many of these sites are serine or threonine residues that are immediately followed by proline residues. Examples of kinases that have been shown to phosphorylate tau in vivo and in vitro are glycogen synthase kinase-3, cyclin-dependent kinase 5 and mitogenactivated protein kinases [30]. Tau hyperphosphorylation seems to be a pathological event and does no occur in the healthy adult brain. Hyperphosphorylated tau becomes longer and stiffer compared to normal tau, which could promote fibrillization of the protein [31].

\section{Genetic Features of FTD}

FTD occurs as a sporadic disease without a family history of dementia. However, a positive family history with an autosomal dominant pattern of inheritance has been shown in 30-50\% of all FTD cases [32, 33]. FTD seems to be heterogeneous also regarding the genetic background as at least three genomic regions have been associated with the disease. In 1994, the first paper was published when linkage to chromosome 17q21-22 was reported in a large pedigree with the disinhibition- 
dementia-parkinsonism-amyotrophy complex [34]. Subsequently, more familial forms with a large variety of clinical and pathological symptoms were linked to this region on chromosome 17, suggesting the same disease locus. At a consensus meeting in Ann Arbor in 1996, those variable familial forms were given the name frontotemporal dementia with parkinsonism linked to chromosome 17 (FTDP-17) [35].

\section{FTDP-17 and Tau Mutations}

In 1998, it was demonstrated that the causative gene for the majority of FTDP-17 families was the tau gene [36-39]. To date, more than 30 tau mutations have been found in FTD pedigrees from all over the world (http:// www.alzforum.org/res/com/mut/tau/table1.asp). According to the functional effect of the mutations, they can be divided into two major subtypes: missense mutations in exons $9,10,11,12$ and 13, coding for the microtubuleassociated regions of the tau gene, and mutations affecting the alternative splicing of exon 10 [for a review, see ref. 40].

The location and subtype of the tau mutations appear to determine the nature of tau pathology, which to some extent could explain the large heterogeneity among FTD cases. While mutations within and flanking exon 10 lead to filamentous neuronal and glial cell pathology, the missense mutations in other exons of the tau gene predominantly lead to neuronal pathology [41]. Furthermore, the exon 10 and 5 -splice mutations result in fibrils consisting predominantly of $4 \mathrm{R}$ tau, while the missense mutations in other microtubule-binding regions are associated with both $3 \mathrm{R}$ and $4 \mathrm{R}$ tau aggregates. The $3 R$ and $4 R$ tau isoforms have been reported to have both structural and functional differences between them [42]. The disturbed $3 \mathrm{R} / 4 \mathrm{R}$ ratio caused by the splice mutations could thus have other pathogenic effects that could trigger apoptosis. It has been shown that $4 \mathrm{R}$ tau binds to microtubules with stronger affinity than $3 \mathrm{R}$ tau. Considering the shift in isoform expression during development, it is likely that $3 \mathrm{R}$ tau is expressed when plasticity is needed, while $4 \mathrm{R}$ tau has a stabilizing role. Overexpression of $4 \mathrm{R}$ tau early in the development or when regeneration of axons is needed could perhaps do enough damage to cause cellular dysfunction and cell death. The overexpression of $4 \mathrm{R}$ tau might also interfere with axonal transport, which could cause synaptic dysfunction and neurodegeneration.

Clinical and Molecular Aspects of

Frontotemporal Dementia
Regarding the missense mutations, the majority are causing reduced affinity and binding to microtubules, which could lead to destabilization of the cytoskeleton and cellular disruption. Free unbound tau would then be available for hyperphosphorylation and aggregation as a secondary event. However, some of the missense mutations seem to have a direct effect on tau aggregation [43]. The gradual aggregation of tau filaments observed with all mutations could result in a toxic gain of function, impairing the normal mechanisms of the cells and resulting in premature neuronal loss.

\section{Genetic Involvement of Tau in Other Tauopathies}

The findings of tau mutations in FTDP-17 resulted in a renewed interest in molecular aspects of other tauopathies. Disorders like corticobasal degeneration and PSP, which are clinically characterized by akinesia, rigidity, occulomotor abnormalities and late-onset dementia have usually been considered as non-hereditary neurodegenerative tauopathies $[17,44]$. However, both disorders were lately associated with certain tau polymorphisms [45-47]. Furthermore, a silent tau mutation (S305S) with a potential splicing effect and two new mutations in exon 1 (R5H and R5L) have been identified in families with PSP, which suggests a direct involvement of tau in PSP [4850]. Another interesting example is the R $406 \mathrm{~W}$ mutation in exon 13, identified by us and others which causes a slowly progressive phenotype that initially resembles Alzheimer's disease [48-53]. Taken together, these findings show evidence of pleiotropy of tau mutations and further indicate the importance of a broad perspective when analyzing for mutations in such complex heterogeneous disorders that are clinically overlapping with other syndromes [for a recent review, see ref. 54].

\section{Hereditary FTD without Tau Mutations}

There are at least five FTDP-17 families in which the genetic defect is still unknown, as mutations in the tau gene were failed to be detected despite thorough investigations [38, 55-58]. A common feature of these families is also the lack of tau-positive inclusions together with positive immunostaining for ubiquitin. We see at least three hypotheses to explain this. Either the disease in these families is caused by mutations in another gene than tau in the same region on chromosome 17 or mutations in the tau

Neurodegenerative Dis 2004; 1:218-224 221 
genes have been missed due to novel properties such as larger deletions or changes in promoter elements that have not yet been investigated. A third explanation would be that the chromosome 17 linkage data were false-positive for these pedigrees and that the true gene would be situated on another chromosome. In the Swedish tau-negative FTDP-17 family, we have made extensive investigations of the tau gene in addition to mutation screening of 6 other candidate genes on chromosome 17q21, however, with negative findings [59]. We can thus not yet fully exclude any of the suggested explanations.

Genetic linkage of familial FTD has also been reported to chromosome 3 in one Danish family although the causative mutation has not yet been identified [60]. Furthermore, in pedigrees with both FTD and ALS segregating, linkage was identified to chromosome 9q21-22 [61]. However, these regions have not been verified by other groups yet [62].

\section{Treatment and Future Perspectives}

Today, limited treatment is available for neurodegenerative disorders such as FTD. There is evidence that treatment with selective serotonin reuptake inhibitors can be useful to reduce the behavioural changes like disinhibition, overeating and compulsions. However, no drugs with a positive effect on disease progress are yet available on the market. Thus, we see several important tasks to solve in future studies.

Considering the low frequencies of tau mutations in the general FTD population investigated by us and others
[63-65], other genetic factors, within and outside the chromosome $17 \mathrm{q} 21$ region, need to be investigated in order to identify the additional causes of FTDP-17 and FTD in general. Identification of genetic components that cause complex syndromes like FTD can give further clues to the pathological mechanisms causing neurodegeneration and lead to new targets for possible treatments. Genetic characterization is also important for classification of a complex heterogeneous disorder like FTD on a genetic, rather than a clinical and histopathological basis. Although extensive research in the field currently generates valuable clues to the unsolved puzzle of tauopathies, the mechanisms through which tau mutations cause neurodegeneration is not yet fully understood. It still remains to be found out whether it is the actual tau aggregates that are devastating for the cells or if these are just a secondary process with no pathogenic role. The new transgenic animal models available today will enable testing of these hypotheses and will provide useful tools for the development of novel and effective treatments of neurodegenerative disorders.

\section{Acknowledgements}

The following foundations are acknowledged for financial support: Gamla Tjänarinnor, The Alzheimer Foundation, Clas Groschinsky's Foundation, Loo and Hans Ostermans Foundation for Medical Research, and the Swedish Medical Research Council (Project No. 10819). This research was supported by the European Union under the programme 'Quality of Life and Management of Living Resources', Key Action 3 'The Cell Factory', Contract No. QLK3-CT-2001-02362.

\section{References}

1 Pick A: Über die Beziehungen der senilen Hirnatrophie zur Aphasie. Prag Med Wochenschr 1892;17:165-167.

2 Alzheimer A: Über eigenartige Krankheitsfälle des späteren Alters. Z Gesamte Neurol Psychiatr 1911;4:356-385.

$\checkmark 3$ Brun A, Englund B, Gustafson L, Mann DMA, Neary D, Snowden JS: Clinical and neuropathological criteria for frontotemporal dementia. J Neurol Neurosurg Psychiatry 1994; 57:416-418.

$\checkmark 4$ Neary D, Snowden JS, Gustafson L, Passant U, Stuss D, Black S, Freedman M, Kertesz A, Robert PH, Albert M, Boone K, Miller BL, Cummings J, Benson DF: Frontotemporal lobar degeneration: A consensus on clinical diagnostic criteria. Neurology 1998;51:1546-1554.
$>5$ Snowden JS, Neary D, Mann DMA: Frontotemporal dementia. Br J Psychiatry 2002;180: 140-143.

6 Mega MS, Cummings JL: Frontal-subcortical circuits and neuropsychiatric disorders. J Neuropsychiatry Clin Neurosci 1994;6:358-370.

7 Neary D, Snowden JS, Mann DMA: Classification and description of frontotemporal dementias. Ann N Y Acad Sci 2000;920:46-51.

8 Lindau M, Andersen C, Johansson S-E, Julin P, Blomberg M, Wahlund L-O, Almkvist O: Functional specialization or interaction in the frontal lobes: Volumetric measurements in relation to cognition and behavior in frontotemporal dementia. Alzheimers Rep 2001;4:45-53.

$>$ Neary D, Snowden J: Fronto-temporal dementia: Nosology, neuropsychology, and neuropathology. Brain Cogn 1996;31:176-187.
10 Mann DM, McDonagh AM, Snowden J, Neary D, Pickering-Brown SM: Molecular classification of the dementias. Lancet 2000;355:626.

11 Tolnay M, Probst A: Frontal lobe degeneration: Novel ubiquitin-immunoreactive neurites within frontotemporal cortex. Neuropathol Appl Neurobiol 1995;21:492-497.

12 Kertesz A, Kawarai T, Rogaeva E, St. GeorgeHyslop P, Poorkaaj P, Bird T, Munoz DG: Familial frontotemporal dementia with ubiquitin-positive, tau-negative inclusions. Neurology 2000;54:818-827.

13 Bigio EH, Lipton AM, White CL 3rd, Dickson DW, Hirano A: Frontotemporal and motor neurone degeneration with neurofilament inclusion bodies: Additional evidence for overlap between FTD and ALS. Neuropathol Appl Neurobiol 2003;29:239-253. 
14 Spillantini MG, Goedert M: Tau protein pathology in neurodegenerative disease. Trends Neurosci 1998;21:428-432.

-15 Iqbal IG, Iqbal K, Quinlan M, Tung YC, Zaidi MS, Wisniewski HM: Microtubule-associated protein tau. A component of Alzheimer paired helical filaments. J Biol Chem 1986;261:60846089.

16 Feany MB, Mattiace LA, Dickson DW: Neuropathologic overlap of progressive supranuclear palsy, Pick's disease and corticobasal degeneration. J Neuropathol Exp Neurol 1996;55:5367.

17 Litvan I: The clinical and pathologic hallmarks of progressive supranuclear palsy. Curr Opin Neurol 1997; 10:346-350.

$\checkmark 18$ Buee-Scherrer V, Buee L, Hof PR, Leveugle B, Gilles C, Loerzel AJ, Perl DP, Delacourte A: Neurofibrillary degeneration in amyotrophic lateral sclerosis/parkinsonism-dementia complex of Guam. Immunochemical characterization of tau proteins. Am J Pathol 1995;146: 924-932.

19 Ghetti B, Piccardo P, Spillantini MG, Ichimiya Y, Porro M, Perini F, Kitamoto T, Tateishi J, Seiler C, Frangione B, Bugiani O, Giaccone G, Prelli F, Goedert M, Dlouhy SR, Tagliavini F Vascular variant of prion protein cerebral amyloidosis with tau-positive neurofibrillary tangles: The phenotype of the stop codon 145 mutation in PRNP. Proc Natl Acad Sci USA 1996;93:744-748.

20 Weingarten MD, Lockwood AH, Hwo SY, Kirschner MW: A protein factor essential for microtubule assembly. Proc Natl Acad Sci USA 1975;72:1858-1862.

-21 Ingelson M, Vanmechelen E, Lannfelt L: Microtubule-associated protein tau in human fibroblasts with the Swedish Alzheimer mutation. Neurosci Lett 1996;220:9-12.

$22 \mathrm{Gu}$ Y, Oyama F, Ihara Y: Tau is widely expressed in rat tissues. J Neurochem 1996;67: 1235-1244.

-23 Neve RL, Harris P, Kosik KS, Kurnit DM, Donlon TA: Identification of cDNA clones for the human microtubule-associated protein tau and chromosomal localization of the genes for tau and microtubule-associated protein 2 . Brain Res 1986;387:271-280.

-24 Andreadis A, Brown WM, Kosik KS: Structure and novel exons of the human $\tau$ gene. Biochemistry 1992;31:10626-10633.

-25 Goedert M, Spillantini MG, Jakes R, Rutherford D, Crowther RA: Multiple isoforms of human microtubule-associated protein tau: Sequences and localization in neurofibrillary tangles of Alzheimer's disease. Neuron 1989;3: 519-526.

-26 Lee G, Neve RL, Kosik KS: The microtubule binding domain of tau protein. Neuron 1989;2: 1615-1624.

-27 Mawal-Dewan M, Henley J, Van de Voorde A, Trojanowski JQ, Lee VM: The phosphorylation state of tau in the developing rat brain is regulated by phosphoprotein phosphatases. J Biol Chem 1994;269:30981-30987.
28 Rosner H, Rebhan M, Vacun G, Vanmechelen $E$ : Developmental expression of tau proteins in the chicken and rat brain: Rapid down-regulation of a paired helical filament epitope in the rat cerebral cortex coincides with the transition from immature to adult tau isoforms. Int J Dev Neurosci 1995; 13:607-617.

29 Hanger DP, Betts JC, Loviny TL, Blackstock WP, Anderton BH: New phosphorylation sites identified in hyperphosphorylated tau (paired helical filament-tau) from Alzheimer's disease brain using nanoelectrospray mass spectrometry. J Neurochem 1998;71:2465-2476.

30 Anderton BH, Betts J, Blackstock WP, Brion JP, Chapman S, Connell J, Dayanandan R, Gallo JM, Gibb G, Hanger DP, Hutton M, Kardalinou E, Leroy K, Lovestone S, Mack T, Reynolds $\mathrm{CH}$, Van Slegtenhorst M: Sites of phosphorylation in tau and factors affecting their regulation. Biochem Soc Symp 2001;67: 73-80.

31 Hagestedt T, Lichtenberg B, Wille H, Mandelkow EM, Mandelkow E: Tau protein becomes long and stiff upon phosphorylation: Correlation between paracrystalline structure and degree of phosphorylation. J Cell Biol 1989;109: 1643-1651.

32 Gustafson L: Frontal lobe degeneration of nonAlzheimer type. 2. Clinical picture and differential diagnosis. Arch Gerontol Geriatr 1987;6: 209-223.

-33 Stevens M, van Duijn CM, Kamphorst W, de Knijff P, Heutink P, van Gool WA, Scheltens P, Ravid R, Oostra BA, Niermeijer MF, van Swieten JC: Familial aggregation in frontotemporal dementia. Neurology 1998;50:15411545 .

34 Wilhelmsen KC, Lynch T, Pavlou E, Higgins M, Nygaard TG: Localization of disinhibitiondementia-parkinsonism-amyotrophy complex to 17q21-22. Am J Hum Genet 1994;55:11591165.

35 Foster NL, Wilhelmsen K, Sima AAF, Jones MZ, D'Amato CJ, Gilman S: Frontotemporal dementia and parkinsonism linked to chromosome 17: A consensus conference. Ann Neurol 1997;41:706-715.

-36 Spillantini MG, Murrell JR, Goedert M, Farlow MR, Klug A, Ghetti B: Mutation in the tau gene in familial multiple system tauopathy with presenile dementia. Proc Natl Acad Sci USA 1998;95:7737-7741.

37 Hutton M, Lendon CL, Rizzu P, Baker M, Froelich S, Houlden H, Pickering-Brown S, Chakraverty S, Isaacs A, Grover A, Hackett J, Adamson J, Lincoln S, Dickson D, Davies P, Petersen RC, Stevens M, de Graaff E, Wauters $\mathrm{E}$, van Baren MJ, Hillebrand M, Joosse M, Kwon JM, Nowotny P, Kuei Che L, Norton J, Morris JC, Reed LA, Trojanowski J, Basun H, Lannfelt L, Neystat M, Fahn S, Dark F, Tannenberg T, Dodd PR, Hayward N, Kwok JBJ, Schofield PR, Andreadis A, Snowden J, Craufurd D, Neary D, Owen F, Oostra BA, Hardy J, Goate A, van Swieten J, Mann D, Lynch T, Heutink P: Association of missense and 5'splice-site mutations in tau with the inherited dementia FTDP-17. Nature 1998;393:702705 .
38 Poorkaj P, Bird TD, Wijsman E, Nemens E, Garruto RM, Anderson L, Andreadis A, Widerholt WC, Raskind M, Schellenberg GD: Tau is a candidate gene for chromosome 17 frontotemporal dementia. Ann Neurol 1998; 43:815-825.

39 Clark LN, Poorkaj P, Wszolek Z, Geschwind DH, Nasreddine ZS, Miller B, Li D, Payami H, Awert F, Markopoulou K, Andreadis A, D'Souza I, Lee VM-Y, Reed L, Trojanowski JQ, Zhukareva V, Bird T, Schellenberg G, Wilhelmsen $\mathrm{KC}$ : Pathogenic implications of mutations in the tau gene in pallido-ponto-nigral degeneration and related neurodegenerative disorders linked to chromosome 17. Proc Natl Acad Sci USA 1998;95:13103-13107.

40 Ingram EM, Spillantini MG: Tau gene mutations: Dissecting the pathogenesis of FTDP-17. Trends Mol Med 2002;8:555-562.

41 Reed LA, Wsolek ZB, Hutton M: Phenotypic correlations in FTDP-17. Neurobiol Ageing 2001;22:89-107.

42 Goode BL, Chau M, Denis PE, Feinstein SC: Structural and functional differences between 3-repeat and 4-repeat tau isoforms. J Biol Chem 2000;275:38182-38189.

43 von Bergen M, Barghorn S, Li L, Marx A, Biernat J, Mandelkow EM, Mandelkow E: Mutations of tau protein in frontotemporal dementia promote aggregation of paired helical filaments by enhancing local beta-structure. J Biol Chem 2001;276:48165-48174.

44 Schneider JA, Watts RL, Gearing M, Brewer RP, Mirra SS: Corticobasal degeneration: Neuropathologic and clinical heterogeneity. Neurology 1997;48:959-969.

45 Conrad C, Andreadis A, Trojanowski JQ, Dickson DW, Kang D, Chen X, Wiederholt W, Hansen L, Masliah E, Thal LJ, Katzman R, Xia Y, Saitoh T: Genetic evidence for the involvement of $\tau$ in progressive supranuclear palsy. Ann Neurol 1997;41:277-281.

46 Di Maria E, Tabaton M, Vigo T, Abbruzzese G, Bellone E, Donati C, Frasson E, Marchese R, Montagna P, Munoz DG, Pramstaller PP, Zanusso G, Ajmar F, Mandich P: Corticobasal degeneration shares a common genetic background with progressive supranuclear palsy. Ann Neurol 2000;47:374-377.

47 Spillantini MG, Yoshida H, Rizzini C, Lantos PL, Khan N, Rossor MN, Goedert M, Brown J: A novel tau mutation (N296N) in familial dementia with swollen achromatic neurons and corticobasal inclusion bodies. Ann Neurol 2000;48:939-943.

48 Stanford PM, Halliday GM, Brooks WS, Kwok JB, Storey CE, Creasey H, Morris JG, Fulham MJ, Schofield PR: Progressive supranuclear palsy pathology caused by a novel silent mutation in exon 10 of the tau gene: Expansion of the disease phenotype caused by tau gene mutations. Brain 2000;123:880-893.

49 Poorkaj P, Muma NA, Zhukareva V, Cochran EJ, Shannon KM, Hurtig H, Koller WC, Bird TD, Trojanowski JQ, Lee VM, Schellenberg GD: An R5L tau mutation in a subject with a progressive supranuclear palsy phenotype. Ann Neurol 2002;52:511-516. 
-50 Hayashi S, Toyoshima Y, Hasegawa M, Umeda Y, Wakabayashi K, Tokiguchi S, Iwatsubo $\mathrm{T}$, Takahashi H: Late-onset frontotemporal dementia with a novel exon 1 (Arg5His) tau gene mutation. Ann Neurol 2002;51:525-530.

$\checkmark 51$ Ostojic J, Elfgren C, Passant U, Nilsson K, Gustafson L, Lannfelt L, Froelich Fabre S: The tau R406W mutation causes progressive presenile dementia with bitemporal atrophy. Dement Geriatr Cogn Disord 2004; 17:298-301.

$\checkmark 52$ Rademakers R, Dermaut B, Peeters K, Cruts M, Heutink P, Goate A, Van Broeckhoven C: Tau (MAPT) mutation Arg406Trp presenting clinically with Alzheimer disease does not share a common founder in Western Europe. Hum Mutat 2003;22:409-411.

-53 van Swieten JC, Stevens M, Rosso SM, Rizzu P, Joosse M, de Koning I, Kamphorst W, Ravid R, Spillantini MG, Niermeijer, Heutink P: Phenotypic variation in hereditary frontotemporal dementia with tau mutations. Ann Neurol 1999;46:617-626.

-54 Schraen-Maschke S, Dhaenens CM, Delacourte A, Sablonniere B: Microtubule-associated protein tau gene: A risk factor in human neurodegenerative diseases. Neurobiol Dis 2004;15:449-460

-55 Froelich S, Basun H, Forsell C, Lilius L, Axelman K, Andreadis A, Lannfelt L: Mapping of a disease locus for familial rapidly progressive frontotemporal dementia to chromosome 17q12-21. Am J Med Genet 1997;74:380 385.
56 Rosso SM, Kamphorst W, de Graaf B, Willemsen R, Ravid R, Niermeijer MF, Spillantini MG, Heutink P, Van Swieten JC: Familial frontotemporal dementia with ubiquitin-positive inclusions linked to chromosome 17q2122. Brain 2001;124:1948-1957.

57 Rademakers R, Cruts M, Dermaut B, Sleegers K, Rosso SM, Van Den Broeck M, Backhovens $\mathrm{H}$, Van Swieten J, Van Duijn CM, Van Broeckhoven C: Tau-negative frontal lobe dementia at 17q21: Significant finemapping of the candidate region to a 4.8- $\mathrm{cm}$ interval. Mol Psychiatry 2002;7:1064-1074.

58 Lendon CL, Lynch T, Norton J, McKeel DW, Busfield F, Craddock N, Chakraverty S, Gopalakrishnan G, Shears SD, Grimmett W, Wilhelmsen KC, Hansen L, Morris JC, Goate AM: Hereditary dysphasic disinhibition dementia: A frontotemporal dementia linked to $17 \mathrm{q} 21-$ 22. Neurology 1998;50:1546-1555.

59 Froelich Fabre S, Axelman P, Almkvist A, Basun H, Lannfelt L: Extended investigation of tau and mutation screening of other candidate genes on chromosome $17 \mathrm{q} 21$ in a Swedish FTDP-17 family. Am J Med Genet 2003; 121B:112-118.

60 Brown J, Ashworth A, Gydesen S, Sorensen A, Rossor M, Hardy J, Collinge J: Familial nonspecific dementia maps to chromosome 3 . Hum Mol Genet 1995;4:1625-1628.
61 Hosler BA, Siddique T, Sapp PC, Sailor W, Huang MC, Hossain A, Daube JR, Nance M, Fan C, Kaplan J, Hung WY, McKenna-Yasek D, Haines JL, Pericak-Vance MA, Horvitz HR, Brown RHJ: Linkage of familial amyotrophic lateral sclerosis with frontotemporal dementia to chromosome 9q21-q22. JAMA 2000;284: 1664-1669.

62 Ostojic J, Axelman K, Lannfelt L, FroelichFabre S: No evidence of linkage to chromosome 9q21-22 in a Swedish family with frontotemporal dementia and amyotrophic lateral sclerosis. Neurosci Lett 2003;340:245-247.

63 Poorkaj P, Grossman M, Steinbart E, Payami H, Sadovnick A, Nochlin D, Tabira T, Trojanowski JQ, Borson S, Galasko D, Reich S, Quinn B, Schellenberg G, Bird TD: Frequency of tau gene mutations in familial and sporadic cases of non-Alzheimer dementia. Arch Neurol 2001;58:383-387.

64 Houlden H, Baker M, Adamson J, Grover A, Waring S, Dickson D, Lynch T, Boeve B, Petersen RC, Pickering-Brown S, Owen F, Neary D, Craufurd D, Snowden J, Mann D, Hutton M: Frequency of tau mutations in three series of non-Alzheimer's degenerative dementia. Ann Neurol 1999;46:243-248.

65 Froelich Fabre S, Forsell C, Viitanen M, Sjögren $\mathrm{M}$, Wallin A, Blomberg M, Andersen C, Wahlund L-O, Lannfelt L: Clinic-based cases with frontotemporal dementia show increased cerebrospinal fluid tau, high apolipoprotein $\mathrm{E}$ $\varepsilon 4$ frequency, but no tau gene mutations. Exp Neurol 2001;168:413-418. 